\title{
Hasty retreat of glaciers in northern Patagonia from 1985 to 2011
}

\author{
Frank PAUL, Nico MÖLG \\ Department of Geography, University of Zürich, Zürich, Switzerland \\ E-mail: frank.paul@geo.uzh.ch
}

\begin{abstract}
Mapping changes in glacier extent from repeat optical satellite data has revealed widespread glacier decline in nearly all regions of the world over the past few decades. While numerous studies have documented the changes of the outlet glaciers of the Northern and Southern Patagonia Icefields (NPI/SPI), information about glacier changes in the Patagonian Andes (to the north of the NPI) is much scarcer. Here we present an assessment of area changes for glaciers mainly located in the Palena district of Chile based on glacier inventories for 1985, 2000 and 2011 that were derived from two consecutive Landsat scenes and a digital elevation model. The analysis revealed a dramatic area decline for the largest glaciers and total area loss of $25 \%$ from 1985 to 2011. The lower parts of several larger glaciers $\left(>10 \mathrm{~km}^{2}\right)$ melted completely. Area loss below $1000 \mathrm{~m}$ elevation was $50-100 \%$ in both periods, and 374 glaciers out of 1664 disappeared. The number of proglacial lakes increased from 223 to 327 and their area expanded by $11.6 \mathrm{~km}^{2}(59 \%)$ between 1985 and 2011. Seasonal snow persisting at high elevations in the 2011 scene was a major obstacle to glacier delineation, so the obtained area change rate of $\sim 1 \% \mathrm{a}^{-1}$ over the entire period is a lower-bound estimate. The observed climate trends (e.g. cooling in Puerto Montt) are in contrast to the observed shrinkage.
\end{abstract}

KEYWORDS: glacier delineation, glacier fluctuations, glacier mapping, mountain glaciers, remote sensing

\section{INTRODUCTION}

Glacier changes are an iconic symbol of climate change impacts all over the world (e.g. Vaughan and others, 2013). As only a limited number of glaciers can be directly observed in the field (e.g. mass-balance and length changes), satellite data provide a spatially more complete overview of ongoing changes, thus complementing the field measurements (e.g. WGMS, 2008). Time series of satellite data acquired with optical sensors (e.g. Landsat TM (Thematic Mapper) and ETM+ (Enhanced TM Plus), Terra ASTER (Advanced Spaceborne Thermal Emission and Reflection Radiometer), SPOT (Satellite Pour l'Observation de la Terre) HRV (High Resolution Visible)) have been widely used to determine glacier extent at a specific point in time, as well as for regional-scale change assessment (e.g. Paul and others, 2004; Racoviteanu and others, 2008; Bolch and others, 2010). With the opening of the Landsat archive at the US Geological Survey (USGS) (Wulder and others, 2012) the determination of glacier changes since the mid-1980s became feasible at a global scale and the number of related publications greatly increased.

Although glacier changes have been determined in mountain ranges on all continents (Vaughan and others, 2013), there are still a number of regions with limited or only local information. One of these regions is located in the northern Patagonian Andes south of Puerto Montt, Chile (Fig. 1). The study site includes several glacier-covered (and partly still active) volcanoes and extended glacierized mountains. The region also holds several protected areas and national parks (e.g. Hornopirén; Pumalín; Corcovado), is densely forested, difficult to access, and characterized by steep terrain with abundant precipitation (Fig. 2). Accordingly, little information is available about the glaciers in this region and their changes through time (e.g. there are no field data).

On the other hand, the large ice masses of the Patagonian icefields to the south have been studied intensively (e.g.
Masiokas and others, 2009 and references therein), as have some glaciers on volcanoes in the Chilean lake district (e.g. Rivera and others 2006, 2008). A recent study by Rivera and others (2012) has also analysed a few of the glaciers investigated here but further back in time. One of the most remarkable glaciers in their study is Glaciar Inexplorado, with a cumulative retreat of $\sim 5 \mathrm{~km}$ since 1961 (i.e. $125 \mathrm{~m} \mathrm{a}^{-1}$ ). This rate has recently increased to $330 \mathrm{~m} \mathrm{a}^{-1}$ according to Rivera and others (2012), likely among the highest retreat rates on record globally for a non-surging and land-terminating valley glacier. Davies and Glasser (2012) also investigated area and length changes for a couple of glaciers in this region (Hornopirén and Corcovado), and found comparably high area change rates for the $2001-11$ period $\left(-0.78\right.$ and $-0.88 \% \mathrm{a}^{-1}$, respectively). However, so far the area changes for all glaciers in the region and their potential relation to topography and climatic variability have not been investigated.

Given these knowledge gaps, our study has several goals: First we determine glacier area changes between 1985, 2000 and 2011 for the entire region covered by two successive Landsat scenes (path 232, row 089/90) using automated mapping of clean ice and manual correction of debris-covered glaciers, water surfaces and shadow (e.g. Paul, 2002; Racoviteanu and others, 2009). The major bottleneck for accurate determination of glacier extents is related to the large amounts of seasonal snow falling in this maritime region (in the mountains $\sim 2-8 \mathrm{~m} \mathrm{a}^{-1}$ according to various sources (e.g. Aravena and Luckman, 2009; Quintana and Aceituno, 2012; Sagredo and Lowell, 2012)), hiding glacier perimeters at higher elevations throughout the year (Fig. 2). Secondly, we present a processing method that helps to detect and remove seasonal snow with multitemporal images, allowing us to provide a lower-bound estimate of the area changes (as some snow remained). Thirdly, we derive topographic parameters from a digital elevation model (DEM) for each glacier and their extents at 


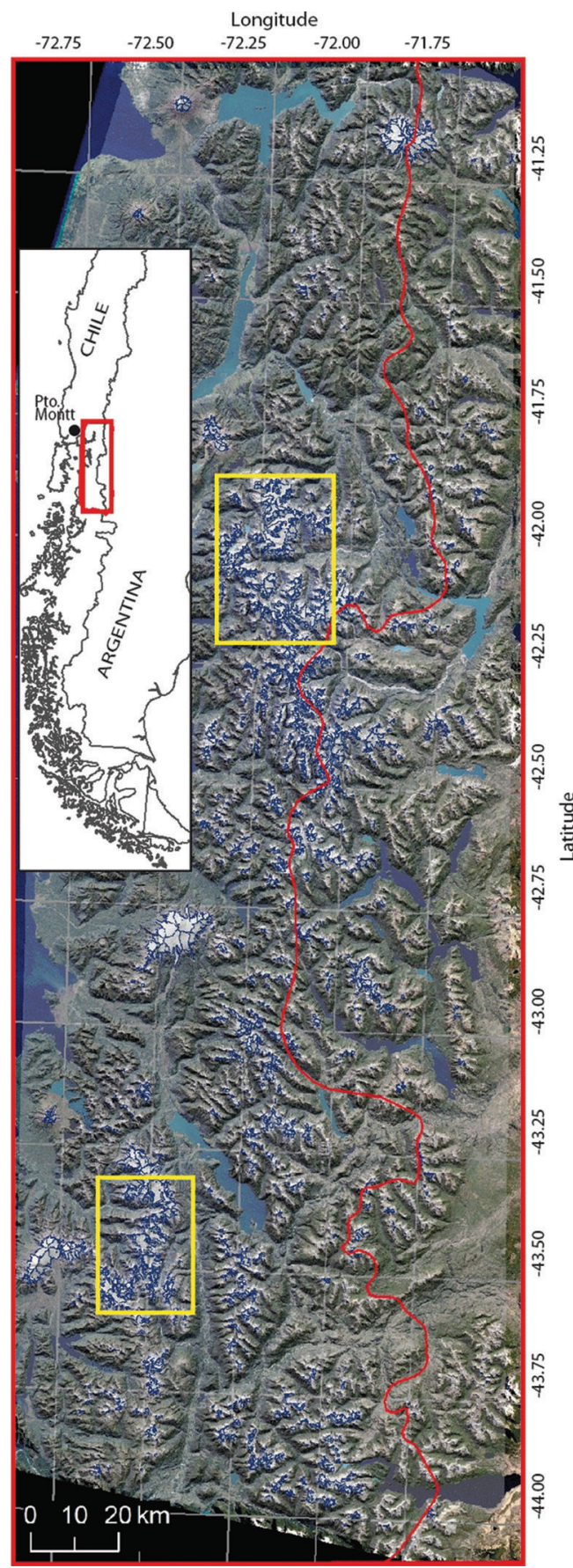

Fig. 1. Location of the study region in South America (inset) and overview of the region and its glaciers (blue outlines) on a natural colour composite of the Landsat data used. The locations of the subregions depicted in Figure 8a and b are indicated by yellow squares.

all dates and analyse how area changes are related to these parameters as well as geographic location. Finally, we determine the increase in the area covered by proglacial lakes due to retreating glaciers and analyse potential relations between their growth, topography and glacier characteristics.

\section{STUDY REGION AND DATASETS}

The region investigated here is located in the northern Patagonian Andes, mostly in the Palena province of Chile and surrounding regions in Argentina. It is located between $40.5^{\circ}$ and $44.5^{\circ} \mathrm{S}$ and is entirely covered by two sequential

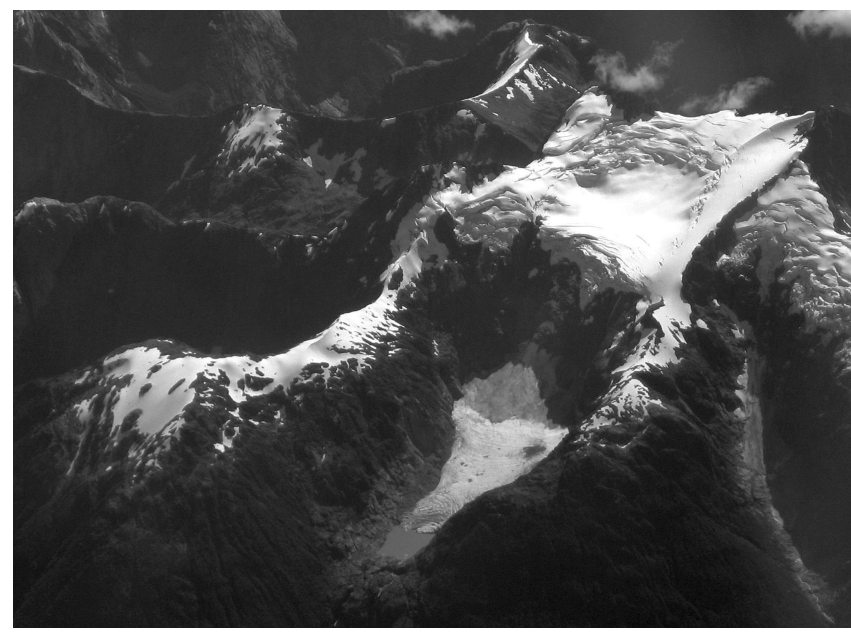

Fig. 2. The steep terrain is responsible for this glacier (Ventisquero La Silla del Diablo) being divided into two parts. The abundant precipitation falling in this region can also be recognized from the image (source: http://www.panoramio.com/photo/49576006, photo taken by Juan Tolosa on 17 February 2011).

Landsat scenes (path 232, row 089/90). With one exception in the north, mountain peaks reach $1800-2500 \mathrm{~m}$ a.s.I. (the exception is Monte Tronador, at $3500 \mathrm{~m}$ ) and the terrain is in general extremely steep. Smaller glaciers are found where the steepness of the terrain only allows limited accumulation of snow such as on ice-capped volcanoes and along topographic ridges at high elevations often having yearround snow cover (Fig. 2). When snow can accumulate over larger areas (i.e. flat regions at high elevations), larger glaciers (valley, mountain or cirque type) can also be nourished. Several glaciers have interrupted profiles and/or terminate in proglacial lakes (Fig. 2), most of which are located behind rock walls, though some have previously broken out (e.g. Worni and others, 2012). Compared to other regions, only a few glaciers exhibit supraglacial debris cover, and, apart from seasonal snow, a key mapping challenge here is the large amount of ice located in shadow (due to steep terrain).

Climatically, the region is highly maritime, with a pronounced west-east precipitation gradient as it is strongly influenced by continuous westerly airflow resulting in abundant precipitation. According to Aravena and Luckman (2009), precipitation reaches up to $3 \mathrm{~m} \mathrm{a}^{-1}$ near the coast, the higher share falling in winter. Towards the northern part of the study region, precipitation amounts decrease to $\sim 1.5-$ $2 \mathrm{~m} \mathrm{a}^{-1}$ (e.g. Aravena and Luckman, 2009; Quintana and Aceituno, 2012). Generally, precipitation data are not available at higher altitudes and best estimates are derived from reanalysis data (e.g. Condom and others, 2007). As a result of the high precipitation amounts and the high $0^{\circ} \mathrm{C}$ isotherm, all glaciers are likely temperate (Carrasco and others, 2008). Frequent volcanic activity covers nearby glaciers with ash, resulting in drastic changes to the albedo and energy balance at the glacier surface, with potential impacts on glacier behaviour (e.g. Rivera and others, 2012).

The Landsat scenes investigated here (obtained from glovis.usgs.gov) were selected to provide the largest possible temporal spread and were acquired on 7 March 1985, 21 February 2000 and 19 February 2011. They are almost cloud-free and have the minimum amount of seasonal snow in the respective year. However, the scenes from 1985 and 
2011 had seasonal snow outside of glaciers at high elevations, partly hiding glacier perimeters. In order to separate contiguous ice masses or glacier complexes into individual glaciers and to derive topographic parameters for each glacier, a DEM is required (e.g. Paul and others, 2009; Kienholz and others, 2013). For this region we used the ASTER GDEM2 (global DEM), as the Shuttle Radar Topography Mission (SRTM) DEM had too many data voids and the void-filled version is of insufficient quality in the void regions. However, the GDEM2 is not free of the typical artefacts for DEMs derived from optical satellite data, mainly in regions of low contrast (e.g. snow surfaces, shadows, lakes) as revealed by an analysis of a hillshade of the DEM. On the other hand, these artefacts have limited impact when glacier-wide averages are calculated (e.g. mean elevation, slope, aspect) (Frey and Paul, 2012) and were therefore not corrected or filtered (e.g. Nuth and others, 2013).

\section{METHODS}

\subsection{Glacier mapping}

Glacier outlines were extracted from the six Landsat images in a standard semi-automatic way, using a ratio of TM bands 3 and 5 and an additional threshold of band TM1 to correct misclassified shadow regions automatically (e.g. Paul and Kääb, 2005). The threshold values for the ratio and band TM1 for the three years (in parentheses) are: 3.0 and 75 (1985), 2.4 and 65 (2000) and 3.0 and 55 (2011), respectively. As the method is unable to capture debris-covered ice (it has the same spectral properties as the surrounding terrain) but often includes parts of water surfaces (which have a similar ratio), these misclassified regions were edited manually using contrast-enhanced versions of the original satellite images in the background. Due to the different image acquisition dates, the glacier area covered by shadow is variable from scene to scene and correct mapping is sensitive to the selected band 1 threshold (see fig. 3 in Paul and others, in press). In the 1985 scene, shadow was most extensive and had partly to be manually corrected by visual inspection using contrast-enhanced images. In part, the high-resolution images available for this region in Google Earth also helped with the identification.

The largest challenge, however, was the proper identification and removal of seasonal snow off-glacier in all three scenes. This is a typical problem when glacier inventories are created in maritime regions (e.g. Paul and Andreassen, 2009; Gjermundsen and others, 2011), as seasonal snow cover hides glacier perimeters at high elevations year-round. Manual correction of seasonal snow is very time-consuming because of the large amount of small snowpatches and the difficulty deciding in each case whether a glacier lies underneath or not. To reduce the workload for the required corrections, a multi-step approach was developed. In a first step, a size filter of $0.05 \mathrm{~km}^{2}$ is applied to remove most of the small snowpatches, i.e. larger than in other studies but the same as applied by Rastner and others (2012) for the same reason. Of course, this also leads to the removal of glaciers that are smaller than this threshold, i.e. the real glacier number and area covered is higher.

In a second step, the amount of manual editing work was reduced by taking advantage of the multitemporal character of the study. Due to different meteorological conditions in each year (e.g. wind direction), the area covered by snow and its spatial distribution varies among the scenes while

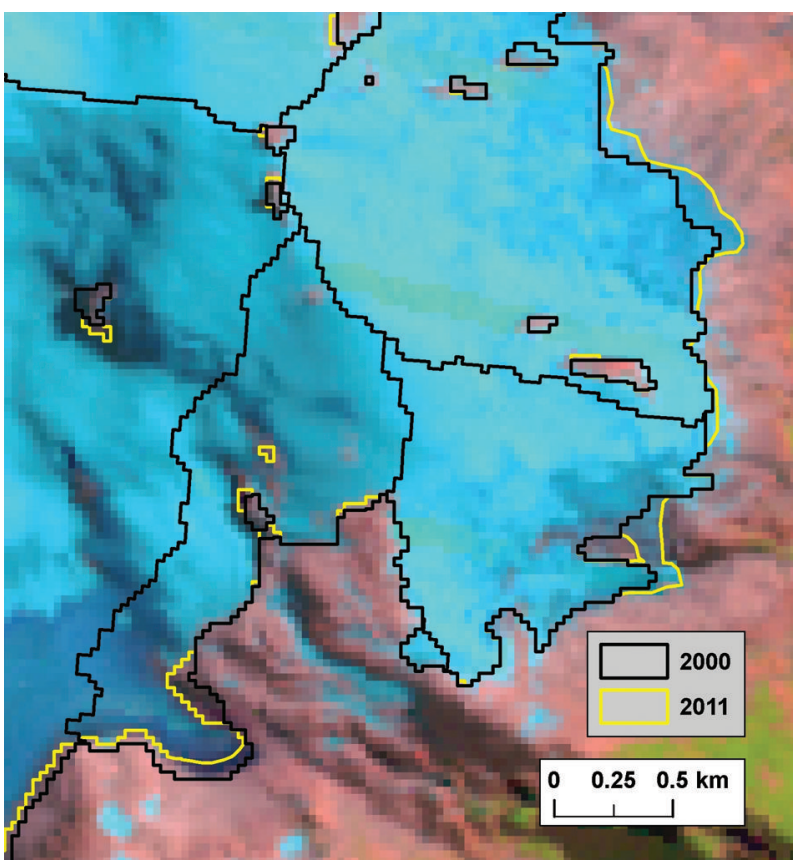

Fig. 3. Not all glaciers lost area from 2000 to 2011. To the east of Monte Inexplorado some glaciers advanced and their outline was manually corrected back to their larger 2011 extent (marked yellow).

glacier extents at high elevations hardly change. Of the three scenes the 2000 scene has the best snow conditions in this regard. Based on the evidence that glaciers have mostly retreated over the entire period (e.g. as obvious from flicker images and previous studies), the corrected glacier extents for 2000 are used as a mask to remove seasonal snow from the 2011 glacier map (cf. also Bolch and others, 2010). This substantially reduced the manual correction workload, but now no glacier can be larger in 2011 than in 2000. A careful inspection of both images (using an animated display) revealed that this was actually not the case and a few glaciers had to be corrected back to a larger extent. The manually digitized yellow lines in Figure 3 illustrate these corrections for a couple of glaciers located just southeast of Glaciar Inexplorado.

In 1985, glaciers were generally larger than in 2000, so snowpatches had to be identified and removed differently. After applying the size filter we carefully checked a selection of small polygons, namely those larger than $0.05 \mathrm{~km}^{2}$ that did not touch a glacier boundary of 2000 . These isolated polygons were identified with a neighbourhood analysis and mostly removed after visual inspection. This step and the additional multitemporal overlay of 2000 on the 1985 glacier mask in shadow regions reduced the manual editing workload, but most of the corrections remained for manual editing.

As a final step we corrected the terminus position of some debris-covered glaciers with the multitemporal outlines from the classified glacier lakes (Section 3.2). If a lake did not touch the glacier boundary at time $t_{1}$, even though at time $t_{2}$ the lake grows into the glacier polygon of $t_{1}$, then the gap between the lake and glacier terminus at time $t_{1}$ is added to the glacier extent, suggesting the glacier was debris-covered and not properly identified at $t_{1}$. Additionally, areas that have been classified as a lake at $t_{1}$ but as ice at $t_{2}$ are reclassified as a lake at $t_{2}$. In most cases the 'wrong' classification was due to frozen and/or still snow-covered lake surfaces. 


\subsection{Classification of lakes}

Lake outlines in the vicinity of glaciers are derived from the year 2011 scene by combining a Normalized Difference Snow Index (NDSI) from Landsat TM bands 2 and 5 with a threshold of -0.37 and an additional threshold for band 4 (digital number <39). In a second step, shadow areas at the time of image acquisition are generated from the DEM and subtracted from the lake map, with all lakes smaller than $0.001 \mathrm{~km}^{2}$ being removed. Due to inaccuracies and artefacts of the DEM as well as clearly different spectral signatures of the lakes (e.g. due to variable turbidity), a complete automatic classification was not possible and manual corrections based on visual comparison with contrastenhanced false-colour composites are applied to $>50 \%$ of all lakes. For the purpose of determining changes of the lakes, we restrict the sample to a subset of all lakes by applying a $500 \mathrm{~m}$ distance threshold to a glacier outline (i.e. all lakes farther away are not considered).

The areas covered by lakes for 2000 and 1985 are derived by digitally subtracting the corrected glacier extents of 1985 and 2000 from the 2011 lake extents. This works best for proglacial lakes that usually form in overdeepenings of the glacier bed (e.g. Linsbauer and others, 2012) and become progressively exposed during glacier retreat. While for most lakes the simple subtraction of glacier extents already provided good results, some lakes still had to be manually edited. This could be due to a change of the lake extent and/or its position, or because a small lake followed the retreating terminus.

\subsection{Drainage divides and topographic parameters}

To split the contiguous ice masses (or glacier complexes) represented by the glacier polygons of the initial raster-tovector conversion into individual glacier entities, digital drainage divides (or watersheds) are required (e.g. Paul and others, 2002). Several semi-automatic approaches are available for this purpose (Kienholz and others, 2013) which all produce valid results but differ in the amount of manual editing required. Apart from that, a key issue here is that differences in the elevations of the DEMs used for orthorectification of the satellite scenes on the one hand, and the drainage divides on the other hand, can result in a poor match of the divides with the glacier outlines along mountain crests. Hence, after digital intersection, a large number of so-called sliver polygons resulted that have been manually corrected (e.g. Frey and others, 2012; Kienholz and others, 2013).

Here we use the semi-automatic method of Bolch and others (2010) which is based on watershed analysis with standard functions implemented in a GIS. As we used a different DEM (ASTER GDEM2) for the divides than was used for orthorectification of the Landsat scenes (L1T product) by USGS (the GLS2000 DEM that is largely based on a void-filled version of the SRTM DEM in this region), a large number of sliver polygons resulted that were manually corrected to the extent possible (i.e. overlaps smaller than about two pixels were not corrected). Though this implies that some individual glacier areas are now too small or too large, this has little impact on change assessment as all glaciers have the same divides in each year. The correction of the divides was based on the 1985 glacier outlines, and basin IDs were also assigned for the 1985 extents. Tracking of glacier area changes through time is also based on the 1985 basins, regardless of a potential glacier split.
After glacier complexes were separated, zonal statistics were calculated using the glacier polygons as a zone and the DEM, slope and aspect grids as the values for the calculation of statistics (minimum, mean, median and maximum for elevation, mean for slope and aspect) following Paul and others (2009). Furthermore, glacier hypsography (areaelevation distribution) was derived for the entire region.

\subsection{Accuracy determination}

We have not determined the accuracy of the derived outlines quantitatively as the required reference data have not been available. However, several factors can be considered in a qualitative sense for a rough estimation of accuracy. In this region the main factors influencing the accuracy of the glacier outlines are: (1) seasonal snow and (2) manual editing of glaciers under debris cover or located in shadow. Errors in the position of drainage divides will influence the area of individual glaciers (e.g. size class assignment), but not the derived changes in area as the same divides are used for all three years. The influence of (1) is likely the largest uncertainty but can only be estimated until a scene with better snow conditions becomes available. As mentioned above, seasonal snow influences mostly small glaciers situated at high elevations, but in a systematic way (overestimation of the real area). As snow conditions were slightly worse in 1985 than in 2000, the result for this period is an overestimation of the area loss while it is an underestimation for the second period. We estimate this bias to be up to $5 \%$ for the first and $\sim 10-20 \%$ for the second period. This has to be considered when interpreting the area changes of small glaciers.

For the accuracy determination related to manual editing, (2), we refer to Paul and others (2013) who derived an accuracy of $\sim 3-5 \%$ (in the mean) from a multiple digitizing experiment of several glaciers with different sizes. Given that only a few glaciers are debris-covered in our study region but shadow caused problems in accurately identifying where glacier boundaries are located, the accuracy of the area determination for shadow-free glaciers is likely better than $5 \%$, but areas can be in error by $\sim 10 \%$ (or even more in individual cases) for glaciers in shadow. However, as overand underestimation can occur, the overall uncertainty due to shadow or debris is small in the mean for the entire sample. Based on these considerations, we assume an overall uncertainty of $5 \%$ for the derived total glacier area in each year.

\section{RESULTS}

\subsection{Glacier inventory}

The number and total area of glaciers per size class is plotted in Figure 4 and shown by values in Table 1. The histogram of the number count has a similar shape to that for other regions of the world (see Pfeffer and others, 2014), but also has some differences. On a global scale, most glaciers are found in the classes $0.1-1 \mathrm{~km}^{2}$, with a near-exponential drop of their number towards smaller and larger glaciers. In our study region, most of the 1664 glaciers analysed (813 in 1985) are found in the class $0.1-0.5 \mathrm{~km}^{2}$, while the classes $0.05-0.1 \mathrm{~km}^{2}, 0.5-1 \mathrm{~km}^{2}$ and $1-5 \mathrm{~km}^{2}$ each contain about one-third of that number. Only $2.2 \%$ of all glaciers are larger than $5 \mathrm{~km}^{2}$, and glaciers in the $1-5 \mathrm{~km}^{2}$ class cover most of the area $(39 \%)$, which is more than all glaciers smaller than $1 \mathrm{~km}^{2}(33 \%)$ and larger than $5 \mathrm{~km}^{2}(28 \%)$. Hence, most glaciers in the study region $(69 \%)$ are small $\left(<0.5 \mathrm{~km}^{2}\right)$ and their numbers have declined substantially $(\sim 1 / 4)$ since 
1985, while glaciers larger than $1 \mathrm{~km}^{2}$ contributed most to the total area loss (73\%) (Section 4.2). With an assumed overall uncertainty of $5 \%$ (could be higher for individual glaciers and 2011), the total area in each year is $1192.5 \pm 59.6 \mathrm{~km}^{2}$ for $1985,951.0 \pm 47.6 \mathrm{~km}^{2}$ for 2000 , and $899.2 \pm 45.0 \mathrm{~km}^{2}$ for 2011 .

Plotting mean elevation vs glacier aspect (Fig. 5a) reveals 100-200 m lower elevations for glaciers facing southeast and south than glaciers facing west. Interestingly, glaciers facing north have lower mean elevation values than those facing west, northwest or northeast. This points to a reduced importance of solar radiation and topographic shading for the location of glaciers. Furthermore, there is a strong dependence on geographic latitude and longitude, resulting in mean elevation differences of $\sim 500 \mathrm{~m}$ for both (Fig. 5b). As the spatial pattern of mean elevation values in Figure 6 clearly reveals, they strongly increase with distance from the coast (decrease in precipitation) but also towards the north (decrease in precipitation and increase in temperature). Though a general upward shift of the mean elevation values through time can be observed (Fig. 5b) the dependence itself does not change much over the observation period.

Plotting mean size vs minimum and maximum elevation (Fig. 7a) reveals the large spread of values for small glaciers. For glaciers larger than $\sim 2 \mathrm{~km}^{2}$ there is virtually no dependence of size on maximum elevation but a clearer dependence on minimum elevation. This implies that a larger accumulation area results in a glacier that can reach farther down. The size dependence of the mean slope of a glacier (Fig. 7b) is much less clear than in other regions, pointing to the different topographic characteristics of this region (e.g. larger glaciers with flat accumulation and steep ablation areas are as frequent as vice versa).

\subsection{Glacier changes}

In Figure 8 we show two example regions with glacier outlines from three points in time and the lake extents in 2011 to visualize the partly extreme shrinkage. The strong retreat of Glaciar Inexplorado II and III seen in the upper right part of Figure 8a (marked as No. 1) has already been shown in Rivera and others (2012). When expanding the view to the surrounding glaciers, the high spatial variability of the changes and the fact that extreme area losses also occurred elsewhere can be seen (e.g. No. 2 in Fig. 8a and examples in Fig. 8b). While most of the smaller mountain glaciers (located at high elevations) show little shrinkage, it seems that in particular the largest valley glaciers with extended tongues at low elevations have lost much of their

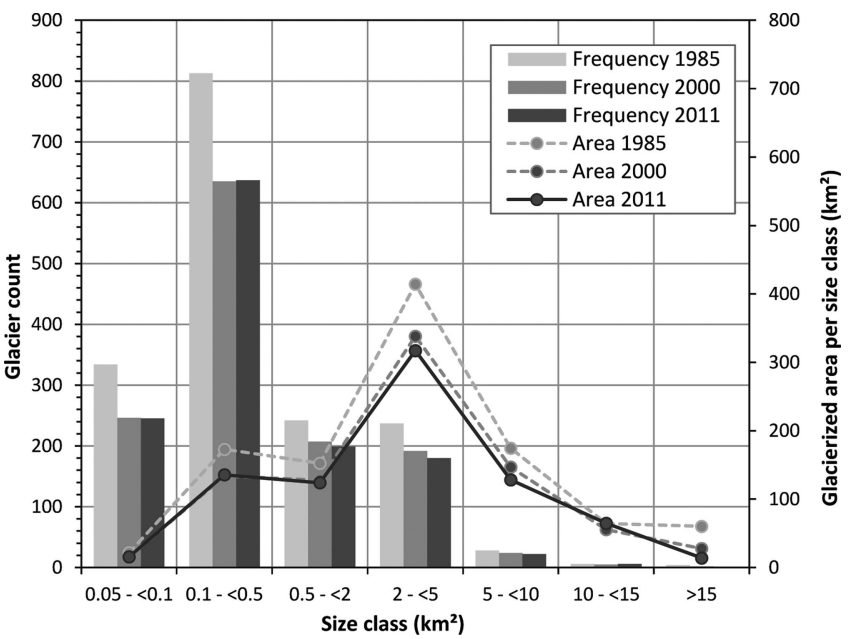

Fig. 4. Number of glaciers (bars) and area covered (line graph) per size class for the three investigated years.

area, mostly by thinning. This impression is confirmed in the example shown in Figure 8b where two larger glaciers (Nos 3 and 4) on the valley floor disappeared. Several other large glaciers in this subregion lost their tongues or large parts of them. In most cases, tributary glaciers were separated from the main tongues at steeper slopes, resulting in a loss of contact with the accumulation area and a simple downwasting of the remaining dead ice afterwards.

When plotting the relative change in area vs glacier size (Fig. 9), the large spread of change values towards smaller glaciers can be seen. The dots at $-100 \%$ are indicative of the 374 (mostly very small) glaciers that completely disappeared between 1985 and 2011. Somewhat smaller relative area change values can be seen towards larger glaciers, but eight glaciers that were larger than $5 \mathrm{~km}^{2}$ in 1985 also lost 28$48 \%$ of their area (most are depicted in Fig. 8). Mean relative area loss values (1985-2011) range from $-80 \%$ to $-41 \%$ for the two smallest classes (corresponding to a reduction in their number of $1 / 4$ ) to between $-18 \%$ and $-25 \%$ for the other classes (Table 1), confirming the limited dependence of relative area loss on glacier size and the strong shrinkage of the larger glaciers (those larger than $1 \mathrm{~km}^{2}$ contributed $73 \%$ of the total area loss). This is the first region we are aware of where the relative loss of area is highest $(-37 \%)$ for the largest size class.

To further elucidate where the area changes took place, we determined the relative area changes also for distinct

Table 1. Number and area of glaciers per size class in the three investigated years, and the absolute and relative area changes

\begin{tabular}{|c|c|c|c|c|c|c|c|c|}
\hline \multirow{3}{*}{$\begin{array}{l}\text { Size class } \\
\mathrm{km}^{2}\end{array}$} & \multicolumn{3}{|c|}{ Count } & \multicolumn{3}{|c|}{ Total area } & \multicolumn{2}{|c|}{ Area change } \\
\hline & 1985 & 2000 & 2011 & 1985 & 2000 & 2011 & & \\
\hline & & & & $\mathrm{km}^{2}$ & $\mathrm{~km}^{2}$ & $\mathrm{~km}^{2}$ & $\mathrm{~km}^{2}$ & $\%$ \\
\hline $0.05-0.1$ & 334 & 246 & 245 & 24.3 & 17.6 & 17.6 & -6.7 & -27.5 \\
\hline $0.1-0.5$ & 813 & 635 & 637 & 194.3 & 150.1 & 152.6 & -41.7 & -21.5 \\
\hline $1-5$ & 237 & 192 & 180 & 466.0 & 380.4 & 356.7 & -109.3 & -23.5 \\
\hline $5-10$ & 28 & 24 & 22 & 196.3 & 165.2 & 144.3 & -52.0 & -26.5 \\
\hline$>10$ & 10 & 7 & 7 & 140.0 & 93.8 & 88.4 & -51.6 & -36.8 \\
\hline Total & 1664 & 1311 & 1290 & 1192.5 & 951.0 & 899.2 & -293.3 & -24.6 \\
\hline
\end{tabular}



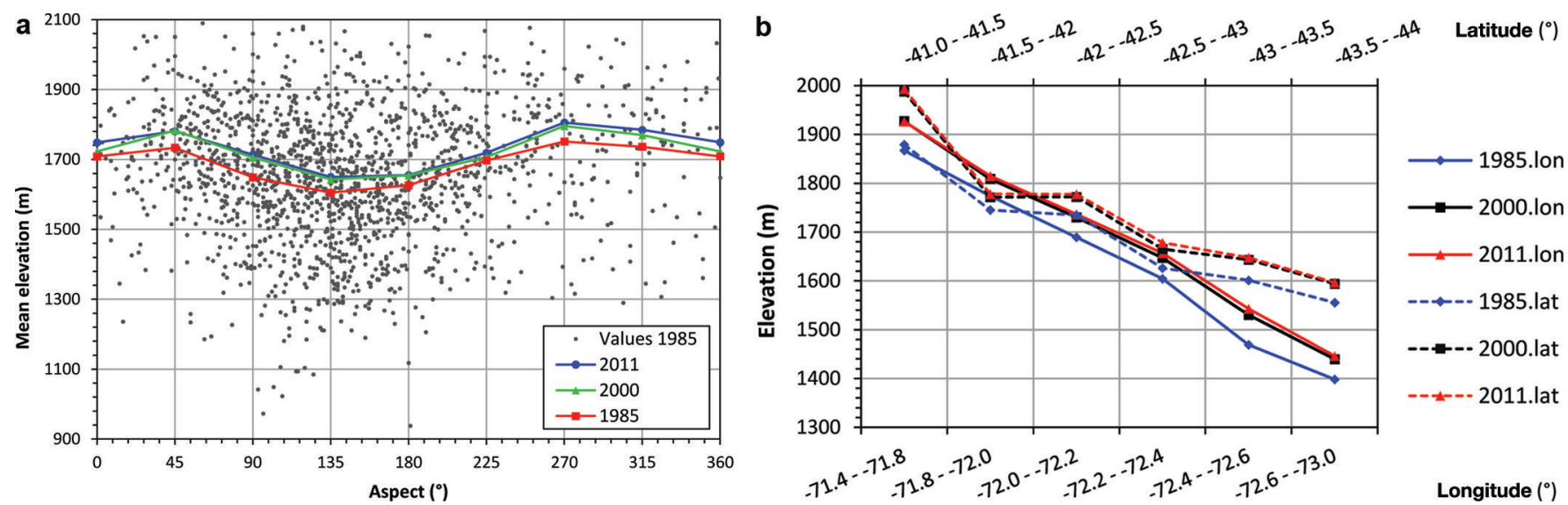

Fig. 5. (a) Mean elevation vs glacier aspect for the 1985 dataset (dots) and sector averages for the three investigated years (lines). (b) Averages of mean elevation vs longitude (solid) and latitude (dashed) for all three years.

elevation intervals (Fig. 10). While the hypsometry for the three years already indicates a substantial area loss at low elevations, the bar graphs showing the relative changes per $100 \mathrm{~m}$ elevation bin confirm this finding. Below $1000 \mathrm{~m}$, between $50 \%$ and nearly $100 \%$ of the area is lost in the respective elevation intervals. Moreover, the bars have about the same lengths in the two periods, indicating that the abundant seasonal snow in the 2011 scene has only a minor impact at these elevations. In absolute terms the strongest changes took place where most of the ice is found $(\sim 1700 \mathrm{~m})$. Above $1700 \mathrm{~m}$ there is little change in the hypsometry from 2000 to 2011, confirming the impact of the seasonal snow at these elevations.

No correlation of area loss with location (latitude or longitude) is found, even when restricting the sample to better comparable glaciers smaller than 1 and larger than $0.1 \mathrm{~km}^{2}$. However, we found clear trends in the average values of minimum and mean elevation (Table 2) that are largely due to the strong shrinkage of ablation areas. The increase of minimum elevation by $46 \mathrm{~m}$ from 1985 to 2011 is even more pronounced $(95 \mathrm{~m})$ when only looking at the subsample of 275 (209 in 2011) glaciers larger than $1 \mathrm{~km}^{2}$. Further excluding glaciers that are in contact with a lake (i.e. have no change in minimum elevation) decreases the sample to 187 glaciers with a mean increase in minimum elevation of $105 \mathrm{~m}$. The related changes in mean elevation are 44, 66 and $61 \mathrm{~m}$ (for the classes all, $>1 \mathrm{~km}^{2}$, and no contact to lakes, respectively).

\subsection{Lakes and their changes}

Together with fast glacier retreat comes a rapid development of proglacial lakes. In principle, this development takes place in the emerging overdeepenings of large and flat tongues of valley glaciers and former confluence regions of ice flow (e.g. Linsbauer and others 2012), but it is also observed for cirque glaciers that have either melted away completely or were reduced to some remnants bordering neighbouring rock walls ( $\mathrm{A}, \mathrm{B}$ and $\mathrm{C}$ in Fig. 8).

Between 1985 and 2011, >100 new lakes had appeared and 65 others had been growing due to glacier retreat, leading to a total area increase of $11.6 \mathrm{~km}^{2}$ or $59 \%$ (Table 3 ). Assuming that all boundary pixels of the changed lake areas are wrong, this increase has an uncertainty (one standard deviation) of $15 \%$ or $\pm 1.74 \mathrm{~km}^{2}$. The rate of growth was $\sim 0.5 \mathrm{~km}^{2} \mathrm{a}^{-1}$ in both periods. Lakes were appearing and growing everywhere between $\sim 600$ and $1900 \mathrm{~m}$, as they are closely linked to the minimum elevation of the glacier tongues which have a large spread (Fig. 6). Due to DEM artefacts over the comparably dark and low-contrast lake surfaces, their elevations could not be determined.

\section{DISCUSSION}

\subsection{Glacier inventory and changes}

The peak of the glacier number in the $0.1-0.5 \mathrm{~km}^{2}$ size class is in line with other regions of the world (Pfeffer and others, 2014), but the steep drop in the number towards the next larger size class has not been observed in previous studies. It might be a result of the steep topography and the maritime climatic conditions resulting in a high number of perennial snow and ice patches along mountain crests (Fig. 2). This number is also influenced by the assigned drainage divides that are to some extent arbitrary without being wrong as their number depends on the rules applied for separating the ice masses (minimum size, consideration of tributaries that are

Table 2. Average values of minimum, mean and maximum glacier elevation for the three investigated years and different subsamples (all glaciers, glaciers larger than $1 \mathrm{~km}^{2}$ and glaciers not in contact with a lake)

\begin{tabular}{|c|c|c|c|c|c|c|c|c|c|}
\hline & $\begin{array}{c}1985 \\
\text { all }\end{array}$ & $\begin{array}{c}1985 \\
>1 \mathrm{~km}^{2}\end{array}$ & 1985 no lake & $\begin{array}{l}2000 \\
\text { all }\end{array}$ & $\begin{array}{c}2000 \\
>1 \mathrm{~km}^{2}\end{array}$ & 2000 no lake & $\begin{array}{c}2011 \\
\text { all }\end{array}$ & $\begin{array}{c}2011 \\
>1 \mathrm{~km}^{2}\end{array}$ & 2011 no lake \\
\hline Minimum & 1434 & 1166 & 1173 & 1468 & 1223 & 1240 & 1480 & 1261 & 1278 \\
\hline Mean & 1657 & 1644 & 1652 & 1694 & 1688 & 1700 & 1701 & 1710 & 1713 \\
\hline Maximum & 1873 & 2078 & 2088 & 1907 & 2104 & 2109 & 1908 & 2113 & 2106 \\
\hline
\end{tabular}


Table 3. Count and area of lakes and their changes in time

\begin{tabular}{lrr}
\hline & Count & Area \\
& & $\mathrm{km}^{2}$ \\
& & \\
\hline New lakes 1985-2011 & 108 & 7.7 \\
New lakes 1985-2000 & 83 & 4.7 \\
New lakes 2000-11 & 25 & 3.3 \\
Growing lakes 1985-2011 & 66 & 4.0 \\
Shrinking lakes 1985-2011 & 6 & -0.1 \\
Total 1985 & 72 & 6.3 \\
Total 2011 & 180 & 17.9 \\
Difference 1985-2011 & 108 & 11.6 \\
\end{tabular}

just in contact with the main glacier, use of topographic structures for subdivision, etc.). Therefore the number of glaciers in a specific size class should not be overinterpreted.

While in the first period $99 \%$ of all glaciers decreased in size, only $51 \%$ decreased in the second period. This is also reflected in the steep decline in the total number of glaciers from 1985 to 2000 but near-unchanged values until 2011 for the two smallest size classes. This can likely be attributed to the larger amounts of seasonal snow at high elevations in 1985 as well as in 2011. On the one hand it might lead to a stronger decrease than in reality until 2000; on the other hand there will be an underestimation of area loss for the second period, as the snow in 2011 could only be removed down to the 2000 extents. While real glacier shrinkage between 2000 and 2011 in these two size classes might have gone unnoticed due to the snow, it is also possible that these glaciers have not changed too much as they are mostly steep and can quickly adjust to climatic change. Furthermore, the large amounts of snow available at the higher elevations in this region (Fig. 2) may have helped to protect these glaciers from further area loss. The next available image with better snow conditions will tell the full story. The other larger size classes have lost area in all years, which might in part be due to the lower elevations they reach (Fig. 7a).

The strong shrinkage of larger glaciers is also reflected in the mean relative area changes per size class. In contrast to all other regions of the world investigated so far, the relative area loss increases towards larger glaciers and the smallest loss rates are observed for the $0.5-1 \mathrm{~km}^{2}$ size class (Table 1 ). However, with the area change for the smallest glaciers possibly underestimated, their relative loss rates might actually be higher than those for the largest glaciers. Nevertheless, the high loss rates found in this region for the largest glaciers are remarkable.

Glacier shrinkage at low elevations is high, reaching 50$100 \%$ below $1000 \mathrm{~m}$ in both periods (Fig. 10). This dramatic decline is also obvious from the area changes shown in Figure 8 and highlights the importance of analysing area changes also in this regard. To some extent it seems that the glaciers rapidly losing their tongues (glaciers A-D in Fig. 8) are the shape of things to come in other regions of the world, once the ice becomes sufficiently thin (e.g. Jouvet and others, 2011). The rapid disintegration of glaciers at this stage is then caused by the comparably flat bed topography of large valley glaciers, resulting in a slowly increasing bed elevation over large parts of the tongue (e.g. Linsbauer and others, 2012). When also becoming disconnected from the accumulation area in this situation, the glacier tongue rapidly turns to dead ice and will inevitably disappear.

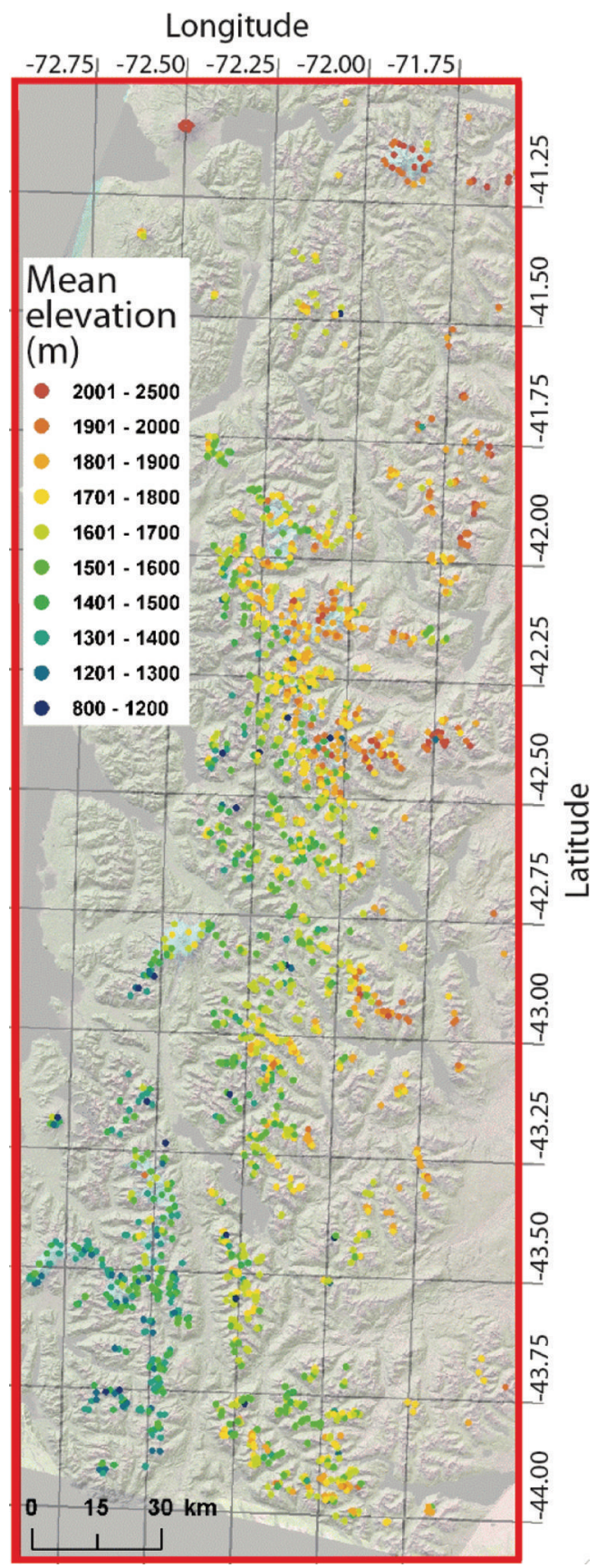

Fig. 6. Spatial distribution of mean elevation for all glaciers larger than $0.05 \mathrm{~km}^{2}$. The increasing trends from south to north and west to east are well recognizable.

The resulting changes in glacier length are also extreme. The case of Glaciar Inexplorado II (No. 1 in Fig. 8a) has already been highlighted by Rivera and others (2012), revealing current retreat rates of $>300 \mathrm{~m} \mathrm{a}^{-1}$. In a cumulative sense, this glacier retreated $>4 \mathrm{~km}$ in 25 years. Similar values between 1 and $4 \mathrm{~km}$ can also be found for other glaciers in the region (see Fig. 8). To give an order of magnitude for comparison with other regions in the world, the kilometre scale is the typical retreat distance of glaciers in the European Alps since the end of the Little Ice Age, i.e. over a period of $\sim 150$ years (e.g. Hoelzle and others, 2003). So far it has been assumed that (on a global scale) glacier retreat in the Alps was strong.

The variability of mean elevation with mean aspect sector ( $\sim 200 \mathrm{~m}$ in altitude) is in line with other regions. However, 

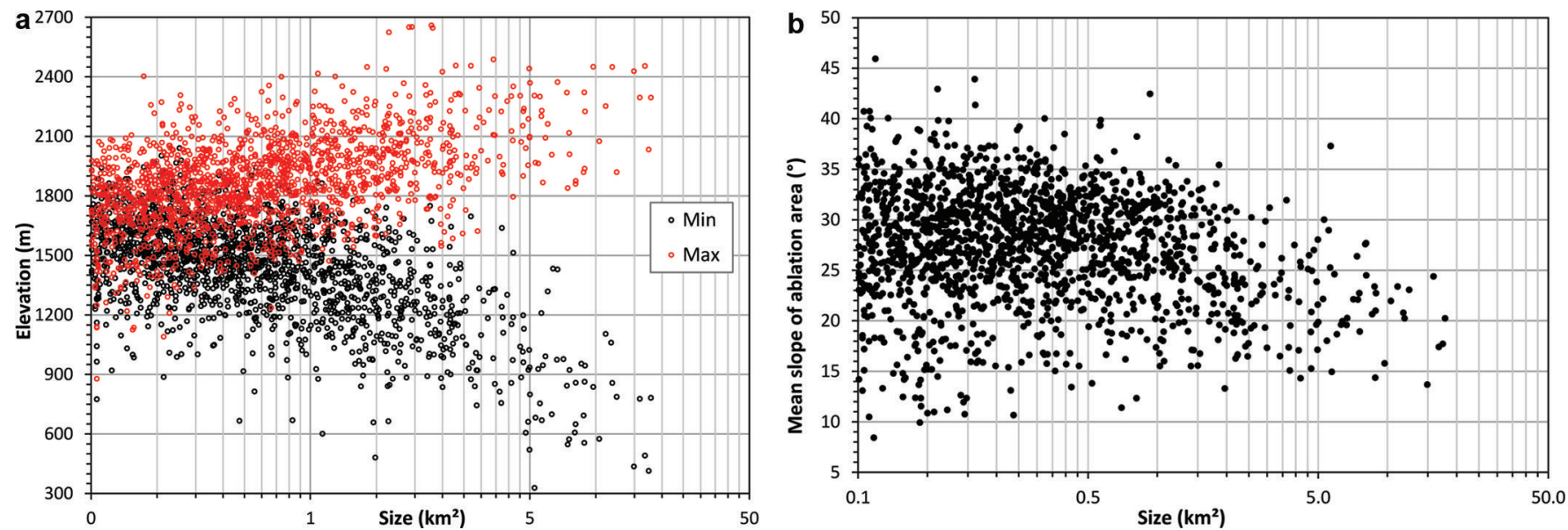

Fig. 7. (a) Maximum (red dots) and minimum (black dots) elevation vs glacier size. (b) Mean slope vs glacier size. Both plots refer to the1985 glacier sample.

the lowest elevations are found in the southeast sector (rather than the south), while the mean is highest in the western sector (rather than the north). This points to a smaller influence of radiation exposure on mean elevation as found in other regions (e.g. Evans and Cox, 2005). The maritime climatic setting might also be a reason for this difference. The strong dependence of mean glacier elevation on distance to the coast (i.e. longitude in this region) shown in Figures $5 \mathrm{~b}$ and 6 (a nearly $500 \mathrm{~m}$ decrease) confirms the strong dependency of precipitation amounts on mean elevation that has also been found in other regions of the world (e.g.
Le Bris and others, 2011; Paul and others, 2011; Rastner and others, 2012). On top of the longitude dependence is a latitude dependence that is likely related to both decreasing precipitation amounts towards the north and increasing mean temperatures (Condom and others, 2007). The dependence on latitude has also been found by Davies and Glasser (2012), though over a much larger latitude range.

\subsection{Accuracy}

Overall, our derived area changes for individual size classes $(-18$ to $-37 \%)$ are higher than the uncertainty of the area
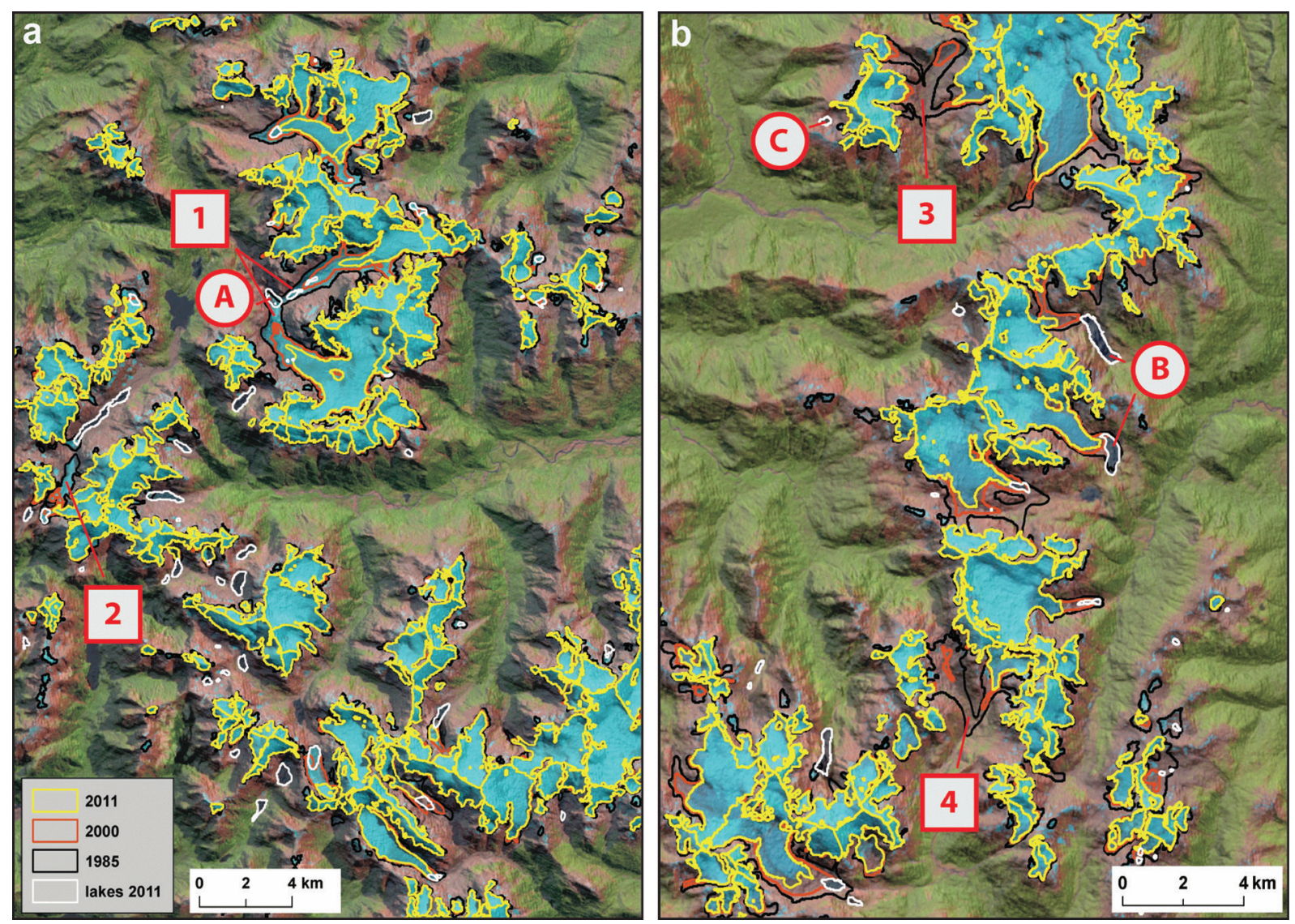

Fig. 8. Glacier changes from 1985 (black lines) to 2000 (red) to 2011 (yellow), and lake outlines (white) for two test sites (see Fig. 1 for location). Glaciers numbered 1-4 lost large parts of their ablation area (or disappeared) over the investigated period, and the annotated lakes represent typical locations of lake emergence: A (at confluences), B (below large tongues) and C (cirques). 


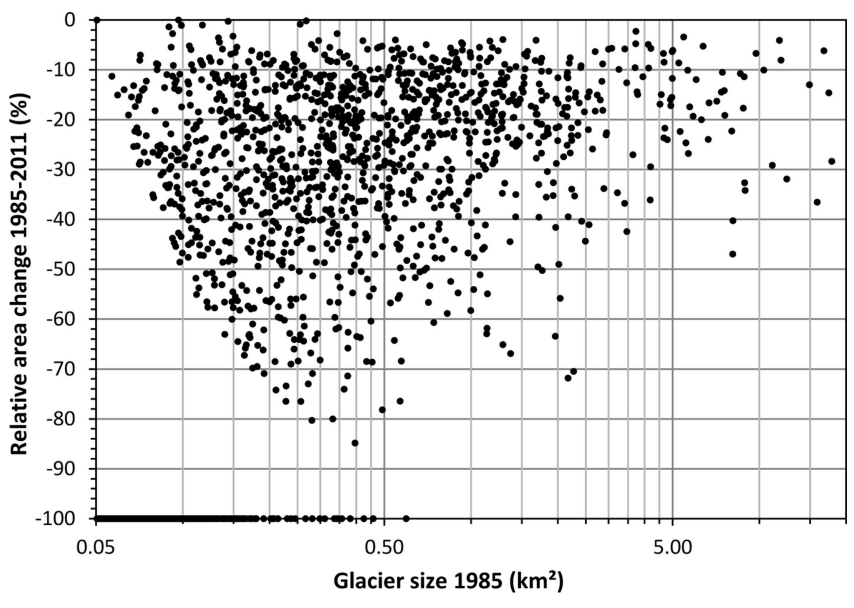

Fig. 9. Relative change in glacier area from 1985 to 2011 vs glacier size in 1985 . Disappeared glaciers can be seen on the $-100 \%$ line.

determination ( $\sim 5 \%$ in the mean over all size classes) and are thus significant. However, for glaciers smaller than $1.0 \mathrm{~km}^{2}$ the uncertainty is in the same order of magnitude as the observed relative area change and can thus be considered insignificant. When the two periods are analysed separately, this only applies to the second period (2000-11), with very small changes (Table 1 ) due to the impact of seasonal snow in 2011. Hence, it is not possible to say with certainty how glaciers in this period have changed, and forthcoming satellite data are needed to reveal the trends. For the other glaciers we assumed a $5 \%$ uncertainty of the total area values for each investigated year (can be higher for glaciers in shadow), resulting in the uncertainties provided above.

\subsection{Lakes}

Glaciers and their changes, especially the global recession trends, are an important topic in environmental science. However, the focus is usually on the issue of glacier melt, its causes and consequences, i.e. on the part of the landscape that is getting lost. On the other hand, there is also 'new landscape' appearing to replace what has been lost. In principle, we have hardly any idea what this new landscape will look like prior to its exposure. This is also due to our limited understanding of the processes occurring at the ice/ bed interface (Cook and Swift, 2012). A most striking landscape change is certainly the development of new lakes in regions where a glacier had once been.

The size and number of the overdeepenings that have filled with water in the study region are already comparable to other largely deglaciated mountain ranges (e.g. the Pyrenees, southwest Europe, or the Wind River Range, Wyoming, USA) as can be seen on satellite imagery. During the study period, all lakes were either growing or stable; none were shrinking outside a one-pixel threshold along the perimeter. This trend will likely continue as many more flat glacier tongues surrounded by steep rock walls exist. In other regions of the world, such lakes pose a natural hazard as they can break out in disastrous floods (e.g. Clague and Evans, 2000; Frey and others, 2010; Bolch and others, 2011; Iturrizaga, 2011). This problem might be smaller in this sparsely populated region of Chile, but it should still be taken into account when planning new infrastructure (e.g. in the context of hydropower projects in the region).

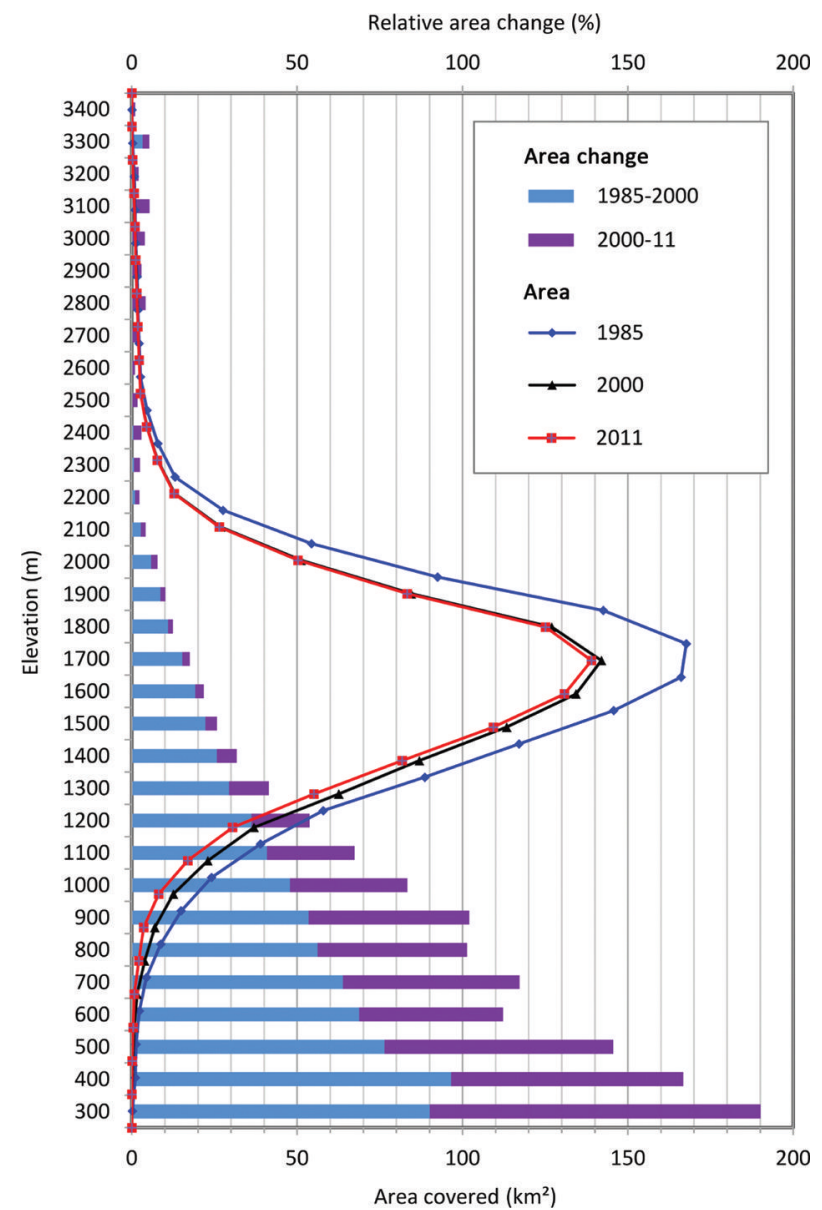

Fig. 10. Area-elevation distribution for the three years (lines) and relative area changes $(\mathrm{d} A)$ for the two periods (bars) in $100 \mathrm{~m}$ elevation bins. Below $1000 \mathrm{~m}$ the area loss in both periods is similar.

\subsection{Climatic interpretation}

In the present study, only area changes have been analysed, but length changes are obvious as well and the satellite images also show a substantial thinning of extant glaciers (e.g. by the emergence of rock outcrops). All this provides indirect evidence that strong mass losses have occurred due to mainly negative mass balances. Apart from volcanic activity, which might be the reason for changes of specific glaciers due to thermal melt, lubrication and ash layers (Rivera and others, 2012), this can be the consequence of increased temperature, decreased precipitation or both. Climatic measurements in this region are sparse in time and space, and existing scientific information is partly contradictory. There is agreement on a slight cooling trend along the coast (Bown and Rivera, 2007; Falvey and Garreaud, 2009) since the mid-20th century; in contrast, temperature trends at higher altitudes seem to be less clear, with conflicting results from different researchers. However, these have low credibility in any case, due to the complete absence of station data above $200 \mathrm{~m}$ altitude. The precipitation trend is clearer, with $\sim-560 \mathrm{~mm}$ between 1960-2000 for Puerto Montt, clearly negative (Bown and Rivera, 2007), but in the end not more than $\sim 20 \%$ of the total amount.

The high sensitivity of glaciers in a maritime climate (Oerlemans and Fortuin, 1992; Raper and Braithwaite, 2006; Rupper and Roe, 2008) together with the decrease in precipitation and possibly some slight warming at higher elevations might be the best explanation for the fast glacier 
retreat. However, in other regions with high precipitation, mass balance is more sensitive to temperature due to its influence on the rain/snow threshold (e.g. Oerlemans, 1997; Anderson and others, 2010). Attempting to explain the massive downwasting and collapse of many larger glaciers in this region from climatic evidence alone is thus unsatisfactory. We assume that the strong response of these glaciers to small changes in climate might be amplified by their special hypsometric setting (e.g. the separation from accumulation areas at high elevations).

\section{CONCLUSIONS}

We have analysed glacier area changes between 1985, 2000 and 2011 for a region in the northern Patagonian Andes (mostly the Palena district in Chile) covered by two successive Landsat scenes. Overall, glaciers have lost 25\% of their total area $\left(1192.5 \mathrm{~km}^{2}\right)$ since 1985 , mostly at low elevations and with little difference between the two periods below $1000 \mathrm{~m}$ elevation. Eight glaciers larger than $5 \mathrm{~km}^{2}$ lost $28-48 \%$ of their area, resulting in a relative area loss that is highest for the largest glacier size class. This might change later (with a better recent scene) due to the current underestimation of the loss of small glaciers at high elevations (which were often covered by seasonal snow), but it is remarkable nevertheless. The complete melting of large glacier tongues on valley floors and the extreme average retreat rates and distances observed here over a 25 year period seem to be unprecedented. More than 370 glaciers completely disappeared and the area of lakes has grown by $59 \%$ or $11.6 \mathrm{~km}^{2}$ over the observation period.

Neglecting temporal changes, mean glacier elevation increases by $\sim 500 \mathrm{~m}$ over a short distance from west to east (away from the coast) and by the same amount over a much longer distance from south to north. Moreover, mean elevation has its minimum in the southeast sector $(1600 \mathrm{~m})$ and its maximum in the west $(1750 \mathrm{~m})$ rather than in the south and north. In a dynamic sense and excluding glaciers terminating in lakes, minimum and mean elevations of all glaciers larger than $1 \mathrm{~km}^{2}$ increased by 105 and $61 \mathrm{~m}$, respectively, from 1985 to 2011. A correlation of the observed changes for any of the other topographic parameters has not been found.

The massive shrinkage of these maritime glaciers is difficult to explain with observed trends in climate (temperature and precipitation), and the special hypsometry of the glaciers (loss of contact to high-elevation tributaries) will also play a role. More detailed studies of the mass balance and climate sensitivity of the glaciers in this region are recommended to elucidate the reasons for the observed drastic changes.

\section{ACKNOWLEDGEMENTS}

This study was performed in the framework of the project Glaciers_cci (4000109873/14/I-NB). We acknowledge the constructive comments and suggestions of two anonymous reviewers.

\section{REFERENCES}

Anderson B and 6 others (2010) Climate sensitivity of a highprecipitation glacier in New Zealand. J. Glaciol., 56(195), 114-128 (doi: 10.3189/002214310791190929)
Aravena J-C and Luckman BH (2009) Spatio-temporal rainfall patterns in Southern South America. Int. J. Climatol., 29(14), 2106-2120 (doi: 10.1002/joc.1761)

Bolch T, Menounos B and Wheate R (2010) Landsat-based inventory of glaciers in western Canada, 1985-2005. Remote Sens. Environ., 114(1), 127-137 (doi: 10.1016/j.rse.2009.08.015)

Bolch T, Peters J, Yegorov A, Pradhan B, Buchroithner $M$ and Blagoveshchensky $\vee$ (2011) Identification of potentially dangerous glacial lakes in the northern Tien Shan. Natur. Hazards, 59(3), 1691-1714 (doi: 10.1007/s11069-011-9860-2)

Bown F and Rivera A (2007) Climate changes and recent glacier behaviour in the Chilean Lake District. Global Planet. Change, 59(1-4), 79-86 (doi: 10.106/j.gloplacha.2006.11.015)

Carrasco JF, Osorio R and Casassa G (2008) Secular trend of the equilibrium-line altitude on the western side of the southern Andes, derived from radiosonde and surface observations. J. Glaciol., 54(186), 538-550 (doi: 10.3189/002214308785837002)

Clague JJ and Evans SG (2000) A review of catastrophic drainage of moraine-dammed lakes in British Columbia. Quat. Sci. Rev., 19(17-18), 1763-1783 (doi: 10.1016/S0277-3791(00)00090-1)

Condom TH, Coudrain A, Sicart JE and Théry S (2007) Computation of the space and time evolution of equilibrium-line altitudes on Andean glaciers $\left(10^{\circ} \mathrm{N}-55^{\circ} \mathrm{S}\right)$. Global Planet. Change, 59(1-4), 189-202 (doi: 10.1016/j.globplacha.2006.11.021)

Cook SJ and Swift DA (2012) Subglacial basins: their origin and importance in glacial systems and landscapes. Earth-Sci. Rev., 115(4), 332-372 (doi: 10.1016/j.earscirev.2012.09.009)

Davies BJ and Glasser NF (2012) Accelerating shrinkage of Patagonian glaciers from the Little Ice Age ( AD 1870) to 2011. J. Glaciol., 58(212), 1063-1084 (doi: 10.3189/2012JoG12J026)

Evans IS and Cox NJ (2005) Global variations of local asymmetry in glacier altitude: separation of north-south and east-west components. J. Glaciol., 51(174), 469-482 (doi: 10.3189/ 172756505781829205)

Falvey M and Garreaud RD (2009) Regional cooling in a warming world: recent temperature trends in the southeast Pacific and along the west coast of subtropical South America (1979-2006). J. Geophys. Res., 114(D4), D04102 (doi: 10.1029/ 2008JD010519)

Frey $\mathrm{H}$ and Paul F (2012) On the suitability of the SRTM DEM and ASTER GDEM for the compilation of topographic parameters in glacier inventories. Int. J. Appl. Earth Obs. Geoinform., 18, 480-490 (doi: 10.1016/j.jag.2011.09.020)

Frey H, Haeberli W, Linsbauer A, Huggel C and Paul F (2010) A multi-level strategy for anticipating future glacier lake formation and associated hazard potentials. Natur. Hazards Earth Syst. Sci. (NHESS), 10(2), 339-352

Frey H, Paul F and Strozzi T (2012) Compilation of a glacier inventory for the western Himalayas from satellite data: methods, challenges and results. Remote Sens. Environ., 124, 832-843 (doi: 10.1016/j.rse.2012.06.020)

Gjermundsen EF, Mathieu R, Kääb A, Chinn T, Fitzharris B and Hagen JO (2011) Assessment of multispectral glacier mapping methods and derivation of glacier area changes, 1978-2002, in the central Southern Alps, New Zealand, from ASTER satellite data, field survey and existing inventory data. J. Glaciol., 57(204), 667-683 (doi: 10.3189/002214311797409749)

Hoelzle M, Haeberli W, Dischl M and Peschke W (2003) Secular glacier mass balances derived from cumulative glacier length changes. Global Planet. Change, 36(4), 295-306 (doi: 10.1016/ S0921-8181(02)00223-0)

Iturrizaga L (2011) Glacier outburst floods. In Singh VP, Singh P and Haritashya UK eds. Encyclopedia of snow, ice and glaciers. (Encyclopedia of Earth Sciences) Springer, Dordrecht, 381-399

Jouvet G, Huss M, Funk M and Blatter H (2011) Modelling the retreat of Grosser Aletschgletscher, Switzerland, in a changing climate. J. Glaciol., 57(206), 1033-1045 (doi: 10.3189/ 002214311798843359)

Kienholz C, Hock R and Arendt A (2013) A new semi-automatic approach for dividing glacier complexes into individual glaciers. J. Glaciol., 59(217), 925-937 (doi: 10.3189/2013JoG12J138) 
Le Bris R, Paul F, Frey H and Bolch T (2011) A new satellite-derived glacier inventory for western Alaska. Ann. Glaciol., 52(59), 135-143 (doi: 10.3189/172756411799096303)

Linsbauer A, Paul F and Haeberli W (2012) Modeling glacier thickness distribution and bed topography over entire mountain ranges with GlabTop: application of a fast and robust approach. J. Geophys. Res., 117(F3), F03007 (doi: 10.1029/2011JF002313)

Masiokas MH, Villalba R, Luckman BH, Lascano ME, Delgado S and Stepanek P (2008) 20th-century glacier recession and regional hydroclimatic changes in northwestern Patagonia. Global Planet. Change, 60(1-2), 85-100 (doi: 10.1016/ j.gloplacha.2006.07.031)

Masiokas M, Rivera A, Espizua LE, Villalba R, Delgado $S$ and Aravena JC (2009) Glacier fluctuations in extratropical South America during the past 1000 years. Palaeogeogr., Palaeoclimatol., Palaeoecol., 281(3-4), 242-268 (doi: 10.1016/j.palaeo. 2009.08.006)

Nuth C and 7 others (2013) Decadal changes from a multitemporal glacier inventory of Svalbard. Cryosphere, 7(3), 1603-1621 (doi: 10.5194/tc-7-1603-2013)

Oerlemans J (1997) Climate sensitivity of Franz Josef Glacier, New Zealand, as revealed by numerical modeling. Arct. Alp. Res., 29(2), 233-239

Oerlemans J and Fortuin JPF (1992) Sensitivity of glaciers and small ice caps to greenhouse warming. Science, 258(5079), 115-117

Paul F (2002) Changes in glacier area in Tyrol, Austria, between 1969 and 1992 derived from Landsat Thematic Mapper and Austrian glacier inventory data. Int. J. Remote Sens., 23(4), 787-799 (doi: 10.1080/01431160110070708)

Paul F and Andreassen LM (2009) A new glacier inventory for the Svartisen region, Norway, from Landsat ETM+ data: challenges and change assessment. J. Glaciol., 55(192), 607-618 (doi: 10.3189/002214309789471003)

Paul F and Kääb A (2005) Perspectives on the production of a glacier inventory from multispectral satellite data in Arctic Canada: Cumberland Peninsula, Baffin Island. Ann. Glaciol., 42, 59-66 (doi: 10.3189/172756405781813087)

Paul F, Kääb A, Maisch M, Kellenberger T and Haeberli W (2002) The new remote-sensing-derived Swiss glacier inventory: I. Methods. Ann. Glaciol., 34, 355-361 (doi: 10.3189/ 172756402781817941)

Paul F, Kääb A, Maisch M, Kellenberger T and Haeberli W (2004) Rapid disintegration of Alpine glaciers observed with satellite data. Geophys. Res. Lett., 31(21), L21402 (doi: 10.1029/ 2004GL020816)

Paul F and 9 others (2009) Recommendations for the compilation of glacier inventory data from digital sources. Ann. Glaciol., 50(53), 119-126 (doi: 10.3189/172756410790595778)

Paul F, Andreassen LM and Winsvold SH (2011) A new glacier inventory for the Jostedalsbreen region, Norway, from Landsat TM scenes of 2006 and changes since 1966. Ann. Glaciol., 52(59), 153-162 (doi: 10.3189/172756411799096169)

Paul F and 19 others (2013) On the accuracy of glacier outlines derived from remote-sensing data. Ann. Glaciol., 54(63 Pt 1), 171-182 (doi: 10.3189/2013AoG63A296)

Paul F and 24 others (in press) The glaciers climate change initiative: methods for creating glacier area, elevation change and velocity products. Remote Sens. Environ. (doi: 10.1016/ j.rse.2013.07.043)
Pfeffer WT and 19 others (2014) The Randolph Glacier Inventory: a globally complete inventory of glaciers. J. Glaciol., $60(221)$, 537-552 (doi: 10.3189/2014JoG13J176)

Quintana JM and Aceituno P (2012) Changes in the rainfall regime along the extratropical west coast of South America (Chile): 30-43 S. Atmósfera, 25(1), 1-22

Racoviteanu AE, Arnaud Y, Williams MW and Ordoñez J (2008) Decadal changes in glacier parameters in the Cordillera Blanca, Peru, derived from remote sensing. J. Glaciol., 54(186), 499-510 (doi: 10.3189/002214308785836922)

Racoviteanu AE, Paul F, Raup B, Khalsa SJS and Armstrong R (2009) Challenges and recommendations in mapping of glacier parameters from space: results of the 2008 Global Land Ice Measurements from Space (GLIMS) workshop, Boulder, Colorado, USA. Ann. Glaciol., 50(53), 53-69 (doi: 10.3189/ 172756410790595804)

Raper SCB and Braithwaite RJ (2006) Low sea level rise projections from mountain glaciers and icecaps under global warming. Nature, 439(7074), 311-313 (doi: 10.1038/nature04448)

Rastner P, Bolch T, Mölg N, Machguth H, Le Bris R and Paul F (2012) The first complete inventory of the local glaciers and ice caps on Greenland. Cryosphere, 6(6), 1483-1495 (doi: 10.5194/tc-6-1483-2012)

Rivera A and 8 others (2006) Ice volumetric changes on active volcanoes in southern Chile. Ann. Glaciol., 43, 111-122 (doi: 10.3189/172756406781811970)

Rivera A, Corripio JG, Brock B, Clavero J and Wendt J (2008) Monitoring ice-capped active Volcán Villarrica, southern Chile, using terrestrial photography combined with automatic weather stations and global positioning systems. J. Glaciol., 54(188), 920-930 (doi: 10.3189/002214308787780076)

Rivera A, Bown F, Carrión D and Zenteno P (2012) Glacier responses to recent volcanic activity in Southern Chile. Environ. Res. Lett., 7(1), 014036 (doi: 10.1088/1748-9326/7/1/014036)

Rupper S and Roe G (2008) Glacier changes and regional climate: a mass and energy balance approach. J. Climate, 21(20), 5384-5401 (doi: 10.1175/2008JCLI2219.1)

Sagredo EA and Lowell TV (2012) Climatology of Andean glaciers: a framework to understand glacier response to climate change. Global Planet. Change, 86-87, 101-109 (doi: 10.1016/j. gloplacha.2012.02.010)

Vaughan DG and 13 others (2013) Observations: cryosphere. In Stocker TF and 9 others eds. Climate change 2013: the physical science basis. Contributions of Working Group I to the Fifth Assessment Report of the Intergovernmental Panel on Climate Change. Cambridge University Press, Cambridge and New York

World Glacier Monitoring Service (WGMS) (2008) Global glacier changes: facts and figures, ed. Zemp M, Roer I, Kääb A, Hoelzle M, Paul F and Haeberli W. World Glacier Monitoring Service/ United Nations Environment Programme, Zürich

Worni R, Stoffel M, Huggel C, Volz C, Casteller A and Luckman B (2012) Analysis and dynamic modeling of a moraine failure and glacier lake outburst flood at Ventisquero Negro, Patagonian Andes (Argentina). J. Hydrol., 444-445, 134-145 (doi: 10.1016/ j.jhydrol.2012.04.013)

Wulder MA, Masek JG, Cohen WB, Loveland TR and Woodcock CE (2012) Opening the archive: how free data has enabled the science and monitoring promise of Landsat. Remote Sens. Environ., 122, 2-10 (doi: 10.1016/j.rse.2012.01.010) 